\title{
Humanization of Care Ethical and Social in Clinical-Care
}

\author{
Graziano Giorgio Maria Paolo, Antonino Graziano, Giovanni Castelli ,Antonio Di cataldo
}

\begin{abstract}
Even primitive people practiced medicine with a religious attitude and blamed supernatural forces to all those diseases that exceeded the experience and thought; the medical report (shaman) - sick could be defined as the "paradigm of the sorcerer." This relational mode started from the assumption that the disease was due to recognizable supernatural factors and therapy, based on the recognition of these factors, was based on precise measures to counter them. An exemplary people in ancient times was that of Egypt, which combines medicine, religion and magic through the identification of therapeutic formulas and magical performances. The priest or Sunu (the one who has compassion) enjoyed esteem as a man endowed with divine and supernatural powers and able to appease the wrath of the gods When the individual doctor-patient relationship is transformed in time, at best it takes place an evolution from dependency to partnership; This change is often the result of work of the doctor who encourages the patient to greater self-sufficiency, to a more mature ability to take responsibility for their own health and to a careful use of resources. Gradually cohere a model of relationship between doctor and patient that sees respected the person as a subject in law to make choices, to have personal points of view and take action on the basis of his beliefs; good working alliance that results, creates a situation of mutual comfort and promotes mutual understanding and acceptance as well as attention to social responsibility. The difficulty of this perspective is to maintain a balance between the conflicting needs of the patient that one part seeks autonomy and the other support and containment. The clinical himself is not free from contradictions: on one side is willing to a total delegation of responsibility, but the other is alarmed by the loss of authority that goes with it I remain ever present Origen: Religious people resort to doctors as collaborators of God, knowing that he has given human beings, like all other sciences, as well as medical science, and that it was he who ordered the grasses sprout from the earth; However, these people also know that the art of the doctors nothing can if God does not want, but so can what he wants.
\end{abstract}

Index Terms-About four key words or phrases in alphabetical order, separated by commas.

\section{INTRODUCTION}

The doctor-patient relationship is often lends itself to bioethical considerations not only because of the discouraging experiences, which often are made in the health

Graziano Giorgio Maria Paolo University of Catania Italy Dpt Sciences Medical of surgery and technologies advanted. Giovanni Castelli MD Policlinico University of Catania Italy.

Antonino Graziano Aggregate Professor .

Antonio Di Cataldo Full Professor University of Catania, Medical School Italy Dpt Sciences Medical of surgery and technologies advanted via S Sofia 86 cap 95125 Catania sector, but by the very nature of this report. It is an asymmetrical relationship; the doctor has in his hands the life of the person in need of care, every decision inevitably affects its people not only in biological and specifically medical terms, but also in the psychological and spiritual They highlight some aspects that do not want to have the claim to an exhaustive treatment but only the intention of creating a constructive line. The well, which is the primary purpose of treatment, as well as the patient's health in its broadest sense, is a good relationship because it is achievable and is achieved only through a human relationship. The doctor-patient relationship, despite an objective diversity of roles and competences, must always be a report integrating purely medical function with the dimension of values of the asset. All this imposes a reciprocity for valuations and the medical goals and the invalid, aware that the protection of health and the patient's life are an intrinsic order of medicine that can not be violated The person who is in a position of vulnerability and fragility wants a question of sense, sending a request for help, looking for an answer of love and acceptance In the report the person searching the overall meaning of his being and his suffering that involves and crosses all sizes, from the physical to the mental to the spiritual. This shows how great the responsibility of the medical and paramedical staff who are required a capacity for listening and empathic understanding in communication. Only by understanding the meaning of questions and through a Socratic dialogue approach and you can enter into dialogue with each other. In the doctor-patient relationship it is important to enlarge beneficence founded on trust(1). The attention to the patient's overall condition prevents to consider the person a pure and simple case. More precisely, the biomedical well, which includes all the effects of clinical interventions on the course of the disease, must be combined either with the idea that the patient's own good, which is what the patient feels, both the good understood as the possibility of exercising the ability to make shared decisions, informed and explicit. Finally, the particular good of the patient can not relate to the ontological well. The doctor has a duty to take care of patient, to protect their health and lives.

\section{HISTORIO GRAPHICAL CRITERIA}

\section{A. First of science.}

Even primitive people practiced medicine with a religious attitude and blamed supernatural forces to all those diseases that exceeded the experience and thought; the medical report (shaman) - sick could be defined as the "paradigm of the sorcerer." This relational mode started from the assumption that the disease was due to recognizable supernatural factors and therapy, based on the recognition of these factors, was based on precise measures to counter them. Consequently any 
therapy was entrusted to those who knew dissolve spells and was surrounded by an aura of sacredness: the priests who extended their own power by exercising the art of medicine, ie procuring health through rituals, sacrifices, fasting, purification, symbolic acts and of worship. In a religious magical atmosphere side the primitive medicine confident for 'extra naturals as the first form of defense against evil and human tension towards the good. An exemplary people in ancient times was that of Egypt, which combines medicine, religion and magic through the identification of therapeutic formulas and magical performances. The priest or Sunu (the one who has compassion) enjoyed esteem as a man endowed with divine and supernatural powers and able to appease the wrath of the gods. We do not know if the priests exercised their medical art at real hospitals, but the ancient sources inform us about the existence of religious sanatoriums, almost always by the sea or near rivers, and use of temples like places of shelter for the sick.(2) And yet, between the pages of ancient history, can be formed like all civilizations, Babylonian, Sumerian, Assyrian, were establish- a strong link between medical practice and religion, bonding methods supported by magic, astrology, teuturgici with strong impact on the sufferer(.3) It 'still the Greek civilization that has more and more intimate relations with Western civilization. From the time of Aesculapius, the Asclepei, Epidaurus, the relationship between the doctor and the patient, was characterized by a strict paternalistic ethics, based on the principle of beneficence (the obligation to act for the good of the patient) and maleficence (the obligation not to cause harm to the patient). It was only the doctor who acted, thought, prescribed and omitted for the sake of the sick without asking the consent. The doctor, thanks to its clinical knowledge, has always had a natural tendency to establish itself as the undisputed arbiter of their own ill health. He considered himself the referee, the magister, the dominus, that conscious of his scientific culture and its professional technical expertise, thought was right and appropriate to decide the patient's behalf. This type of relationship is highly unbalanced and asymmetrical: the sick person is considered very passively, unable to know and be able to act on his physical health(.4) In ancient Greece and Rome itself, the doctor was interested in the natural power of the body, coupled fluid mechanism, whose imbalances were able to explain the onset and evolution of different diseases. The verbal report was almost canceled and the therapeutic act was intuitive and stereotyped centered on the research of the standard and the natural pattern. Hippocrates, considered the father of medicine, has left an oath, still used since the times of Clement VII and lent in the Faculty of Medicine, as well as a set of 72 books of dubious attribution. The writings contained in it, especially the Aphorisms, show a rational and critical approach to the disease and a high view of the art medical ethics: the sick, has no individual dignity and the doctor undergoes a rigorous behavioral fee constitutes' single point of moral reference, human and honest. The doctor, as we learn from the Oath, must be driven by love for the sick, free from other interests, practical and obsequious towards purity and religiosity of medical science. Hippocrates medical art comes out of the temple, no longer considered a priest competent from a medical point of view. Hippocrates introduced the concept of method, centered on a dual relationship, dialogue between doctor and patient, says the man in the environment and seeks to demonstrate the laws that regulate its existence.(5) It also entertains first on medical ethics, in fact urges the doctor to be discreet and respectful to the pain of his disability, mild then in prescribing treatment. The doctor then must possess the art of speaking and listening; the patient is called to fulfill their duties and direct collaboration, that is, to establish a sympathetic relationship with the doctor. By Galen to Paracelsus the physician-patient substantially does not change the method and the ratio remains always of paternalistic and increasingly showed ethically inappropriate, because it infringes the individual right of self-determination and patient autonomy. The technology available to the physician was then quite poor, with an effective impotence on the diagnostic treatment plan. The physician pre-modern certainly had a strong bond with the patient and the therapeutic activity often coincided with the history, which he derived almost exclusively way of interpretation, while the patient is generating the noise narrative acted as cathartic strength and as a placebo. The dependence of the patient by the medical professional is part of the tradition. Ancient times the doctor's duty is to rescue and the patient's duty is to welcome his help as it came from the minister of a cult with the power of life or death; he acts to procure a benefit objectively against the disorder caused by the disease, its proposals are advantageous by definition, his professional responsibilities is more religious than juridical, so in case of error the impunity is virtually guaranteed. The patient has to adapt to the authority of the care provider and should subordination. Christianity has promoted the image of the Good Samaritan doctor who leads the patient to recovery, so medicine and health are gifts of God detached from everyday life, by human laws, the context in which the disease is inserted. With Pasteur and Koch founded modern medicine, but the doctor-patient relationship remains a "history of silence" in the sense that the patient remains substantially in the relationship with the physician, taxable person, following your doctor's guidelines, without intervening in care process, because "trust him and he trusts in silence" without any questions. This cultural tradition implies that the Consent to Medical is implicit and given once and for all; the patient therefore has no means to oppose the decisions of the physician; until the nineteenth century, he is regarded as an adolescent, mature decisions for some and not for others. The clinic is one of the fields in which the subject has a limited sovereignty right of choice. With modernity paternalism it has not disappeared, but has cracked; discovered the power of intellect and the existence of equal rights for all, the individual can have confidence and can make personal choices. The social changes that have favored the transformation from the patronizing attitude towards a partnership relationship can be summarized as follows:

- Changes in the M / P ratio following development, in a secular society, pluralistic and democratic, the concept of freedom and autonomy of the individual. For each medical procedure requires a free and informed consent;

- Social and historical forces have changed the placement of medicine: as an elite science to a context of greater democracy and equality; 
- The doctor has lost the authority of the one who takes decisions in all aspects of health care;

- Technology has increased the complexity of treatments and decisions to be made;

- The economic aspect is increasingly important in influencing decisions. It is increasingly the responsibility for appropriate use of resources, then the physician must balance his commitment to the individual with the duties to the whole society. As technological progress has allowed the doctor to be able to make the diagnosis of organ disease more and more correct, the shamanic aspect was reduced to the benefit of the professional one. When the individual doctor-patient relationship is transformed in time, at best it takes place an evolution from dependency to partnership; This change is often the result of work of the doctor who encourages the patient to greater self-sufficiency, to a more mature ability to take responsibility for their own health and to a careful use of resources. Gradually cohere a model of relationship between doctor and patient that sees respected the person as a subject in law to make choices, to have personal points of view and take action on the basis of his beliefs; good working alliance that results, creates a situation of mutual comfort and promotes mutual understanding and acceptance as well as attention to social responsibility. The difficulty of this perspective is to maintain a balance between the conflicting needs of the patient that one part seeks autonomy and the other support and containment. The clinical himself is not free from contradictions: on one side is willing to a total delegation of responsibility, but the other is alarmed by the loss of authority that goes with it.

\section{B. Towards a new medicine}

The understanding of the importance of the relationship between the doctor and the patient can be traced back to Sigmund Freud (1856-1939) who, a century ago, highlighted an unconscious projection of the patient on the therapist of moods, emotions and desires (transference) that in turn activate the therapist feelings that can be transferred to the patient (counter transference). It is due to the doctor and psychoanalyst Michael Balint (1896-1970) the merit of recognizing that these two aspects are factors of primary importance in the relationship between each health professional and his patient. Over the last decades of the twentieth century there have been profound changes in the way that is explicit medical practice, which raised doubts and heated debates on the traditional medical ethics validity. (6)Among the most significant changes we can remember, on the one hand, the significant scientific and technological progress, which has allowed medicine to have a real technical capacity to intervene with some success (just think of the vicarious machines in intensive care units, the machines dialysis, to techniques for assisted reproduction, to organ transplants, etc.) and on the other, the demand for more and more areas of autonomy on the part of citizens who, in health care, has helped create a favorable environment for the approval in 1973 of the "Charter of Patient rights". This document claimed the patient's right to be informed and to be a part of the therapeutic decisions concerning him. An important claim which involves the recognition of the patient's wishes and respect for their decision-making autonomy. According to Veronesi, Medicine in the early twentieth century it was characterized by three main lines: the first was the science, the second art, the third magic, that is, the ability to interact with the patient via a particular ascendant.(7) And 'well it is known that the reactivity to a health problem differs from person to person, in relation to different biological variables (age, sex, race), sociological (cultural, personal history, family, lifestyle), psychological ( pain threshold and subjectivity to manifest it, its ability to correlate symptoms he accused to a specific disease, states of mind, knowledge, memory), spiritual (religion, ethics). The doctor-patient relationship is affected both by all these variables, involving physical and emotional symptoms that many other elements, such as the continuous technological progress, the emphasis of preventive procedures, the knowledge mediated by the internet, the patient's awareness to no longer be subordinate to the doctor through informed consent. The significance of the close personal relationship between doctor and patient can never be over-emphasized, since this depends on an infinite number of diagnoses and therapies. One of the essential qualities of the physician's interest in the man, as the secret of patient care is care for it. The doctor-patient relationship, typical relationship of care, it is a complicated relationship, hard, asymmetrical and tormented, and is certainly influenced by the transference and counter transference as before Freud had amply demonstrated. (8)Giorgio Bert, in a clear and interesting article writes: change the world, change the tools and knowledge, but does not change the concept of the therapeutic relationship, which is and remains the most ancient roots of medicine.(9)

An asymmetrical relationship is also affected by other factors that act as real barriers of communication, as defined by Thomas Gordon.(10) Recall of all the non-compliance, that is, the patient's poor or unavailable to accept or deny the signs of health. When there is a situation of non-compliance the communicative relationship becomes confrontational, useless, even non-existent, and the relationship is extinguished. The patient, in such circumstances, not only does not accept the doctor's prescription which he addressed, but also tend to oppose it. It goes without saying that the non-compliance can be established when it is reduced to no understanding of the message: overly technical language, the incomprehensibility of the language as sick stranger, specificity of the disease, acute, chronic with mnesic and cognitive disorders. The patient perceives the authoritarianism of the doctor, which would reduce his free behavior and activates a defense mechanism, defined by Brehm as "psychological reactance", which tends to defend freedom threatened or eliminated. The doctor-patient relationship, for all this, today, according to Edward Shorter, a clash tormented and angry, with the conclusion of anger and frustration of both. Shorter writes: I do not take with the doctors if they do not try to practice psychotherapy on a formal level. I accuse them of ignoring the therapeutic power of the medical examination itself. The healing power of the consultation is in purifying the patient derives from telling their stories to someone they trust as a healer. Some have now 
replaced the term "patient", "patient", (11)with that totally inappropriate "customer", in the sense that the subject chooses and pays the doctor, whose submit specific requests and precise and he expects as many clear answers, they should follow certain results. In these terms often the doctor warns this report only as an exclusive or predominant request for help, while ignoring what relational requirement in it is enclosed. We believe that the clinical medicine must certainly express itself through a helping relationship,(12) but clarifies that the "needs" of the medical information occurs both involving ongoing training, both through the knowledge of the patient and not just the disease. In 1973, in the USA, the American Hospital Association approved the Patient Bill of Rights, which claimed the patient's right to be informed and to be a part of the therapeutic decisions concerning it. From here the paternalistic model was replaced by a contractual ethical model, characterized by a relational report. In an article in the BJGP it said that despite the availability of more appropriate medical care and sophisticated technology constantly evolving, which allowed more and more targeted diagnosis, $25-50 \%$ of patients went to the doctor, even without obvious causes pathological, invalidating, in this last situation, in many respects, a constructive relationship (13). E 'task of a careful medical ensure that its relationship with the patient not only to be a cold and aseptic filling in a questionnaire, or in a hurried interview monocratic with purely passive function of the patient, but is able to effectively explore its lived, understanding empathically emotions, doubts and fears. Currently, known Palma Sbreccia, medicine seems to suffer the abundance of means and the poverty of purpose, it also requires a critical reflection, of a philosophy of medicine, ie a discourse on the same medicine, on his essence and specificity. The medicine is not only a knowledge or just a technique and even the synthesis of both because it is a relationship that rises to the need for care. I remain ever present Origen: Religious people resort to doctors as collaborators of God, knowing that he has given human beings, like all other sciences, as well as medical science, and that it was he who ordered the grasses sprout from the earth; However, these people also know that the art of the doctors nothing can if God does not want, but so can what he wants.(14)

\section{THE CONCEPT OF PERSON}

The treatment of disease, the relief of suffering and the extension of basic care, according to the principle of fairness and justice, are the basic medical art characters. From this perspective comes the need for humanization of medicine that animates and sustains the very idea of scientific progress and the status of medicine, whose purpose is the person. Many differences are born in the indication of the initial moment of its existence or even in the definition of death or when there is no longer the person failing in some capacity. Boethius said that the person is the individual substance of a rational nature, so an individual of a rational nature which is man.(14) But the person is not a concept, its rationality is linked to human nature regardless of its operations, namely the ability or not to try to be rational. Unlike the concept of utilitarian Peter Singer where every person be rational and self-conscious and therefore the quality of the person is based on the ability to experience pleasure and pain. Undoubtedly self-awareness and rationality are the person indices, but these operations which indicate the person does not identify with it. You can not identify the acts with the subject that produces them. Is there a subject self-conscious, rational and free capable of implementing concepts that would otherwise remain only abstract concepts. Conceive of man as a person means to consider it in its entirety as spirit and body. The transition from power to act never changes the nature of a being, but simply encourages its full manifestation. A being can become what it is by its nature and so nothing can become a person without already being a person. The human individual is ontologically the same substance as a person he was. The substance is not subject to change, but changes its ability to possess certain skills.( 15)So all human beings are persons. We could even say that the person is a unique and unrepeatable individuality of transcendent nature which carries an ontogenetic law of development. The transcendent and spiritual nature of man indicates the sublimity of his being that Christ has revealed himself as the image of God and the source of which is the act of God the Creator: The question of personal identity is reflected in the doctor-patient relationship, as symbolic expression of the human condition marked by the vulnerability. A key issue is the ability to grasp the unity prior to the relationship, namely the experience and living of the person, whose spiritual and psycho-physical integrity, always requires protection, proportionate care, political and social choices based on the principle of Justice. Our person is more of a non-continuous components together: something integrates all the information coming from inside of our bodies both from the outside world, as well as from our personal history, the illusion of being a unique identity. It understands that every human being is a person and that the orderly coexistence for the good implies respect for human rights are grounded in human nature. From the concrete phenomenological existence, you can recognize the dignity of each person, in a universal way. Hence the assumption of responsibility towards their own, but also towards the choices and consequences that decisions and medical actions are likely to cause. (16)In reference to the new biomedical emergencies, together with the challenges of neuroscience, ethics is not enough to restricted regime. The enlargement of the view of the world can promote, through the technological age critical consciousness, a progressive globalization of rights such as the right to life, to subsistence, to the care and protection of persons whose preciousness and beauty transcends the cramped and austere space the individual profit. In the perspective of personalistic bioethics that seeks to reflect on the spiritual integrity, psycho-physical and relational, the ontological status of the person includes a reference to the starting point, that is the original synthetic unity of body and spirit of the human being unit.

The dignity of every person is therefore justified in the same dynamic order of his being. Human dignity resides in the act of the whole person; the presence of the human being stands as question of being and therefore being the person asks as an act of justice Recognition, warmth, hospitality and the defense of its integrity. The transcendent, spiritual dimension of the person has its ultimate roots in the truth of man's creation, intelligent finite being, who lives in a relationship with God in whose image and likeness. Sacred Scripture teaches that man was created "in the image of God" capable 
of knowing and loving his Creator, and which was formed by Him above all earthly creatures which of them ladies, to govern them and use them for glory of God. And 'within this communion of love that the mystery of all being finds its full meaning(.17)

\section{HEALTH AND DISEASE.}

Reflect on the themes of health and disease, suffering and hope of the human person, it means researching the sense that these experiences have in the personal project of a person's life. I introduce reflection observing what the attitude of contemporary culture in the face of health and pain, in front of the living and dying, has changed in recent decades; a change of the rest are still in place, was so evolution. In a general way we can say that the man of our time has increased the sense of responsibility towards these life situations, from a behavior that accentuated the feeling of passivity and dependence, to a way of being and to manage these conditions in a much more active and responsible. Then the concept of health-illness is then considered in a wider and more articulated. One would say that today's man wants to not only live, but "live fully", attentive to the various dimensions of his being: organic, psychological and social. Against the suffering, it has become more aware of the plurality of causes that can provoke, as well as the variety of ways in which it can express itself. The experience of suffering also is experienced today more as a provocation and challenge not as a reality to accept and to bear patiently. It 'a trend that emphasizes the free and active aspect that arises before the reality with a positive attitude. The result is that every situation of pain, such as illness, failure, and other misfortunes, are seen primarily as a call of freedom and responsibility, as a denunciation of a need, a lack of which it requires the commitment of freedom. And 'then it grew the sense of human responsibility for both the causes that induce suffering and disasters, both man himself must do when a misfortune, suffering is taking place. There is to be borne in mind also the change of the cultural horizon of science and technology of our time, which refers to the evolutionary model of the cosmos and human existence, not without major repercussions on the meaning that illness and pain, health and they have hope for the contemporary man. In science and contemporary culture goes increasingly asserting the dynamic and evolutionary conception of the world and human existence. This conversation begins with a consideration on contemporary medicine. This opening is developing more and more to the totality of the human person. And 'now it entered the common language to talk about a psychosomatic or holistic medicine in order to understand the disease not only as a fact that affects the natural data of the patient, but that affects the existential given, the experience of the subject. No longer considered sufficient to cure the disease, you must get to take care of the sick person, seen in the plurality of its needs that maybe the disease blew chaotically. This is known, in the health sciences of the passage to be implemented by not only cure, but also to take care of others. It is time to understand the reasons that are driving this transition. I will analyze this aspect taking the concept of health and to disease, trying to bring out the status of the human person when it enjoys the status of good-health and vice versa, when it is in ill-health. In a second step, I propose to raise the interest on the type of rationality suited to the world of health now seen in this broader perspective. $(18,19)$

\section{CONCEPT OF HEALTH.}

Recently it was Hans Georg Gadamer to draw attention to the difficulty encountered in wanting to define the health condition: We know roughly what they consist of diseases, as they are as it were characterized by the revolt of the fault. They manifest themselves as an object, as something that resists and then must be broken. It 'a phenomenon that one can observe carefully, judging the clinical value, and do it with all the methods provided by a knowledge objectively based on modern science. Health rather curiously exempt from everything, can not be examined, since its essence is precisely to hide. Unlike the disease, health is never a cause for concern, indeed, you are almost never aware of being healthy. It is not a condition that invites or cautions to take care of themselves: In fact implies the amazing ability to be forgetful of themselves. Some help to understand the sense of health as integrity, can be the use of linguistic root of the word "health." Be whole, be identical to themselves it means two things. First, be free from anything that impairs or prevents the integrity; secondly, be intact indicates the implementation of the entire 'potential' available, the achieve the goal using what is proper to man. It reports the conclusion arrived at Jaeger, a scholar of the problems of medicine: the doctor's task is to restore the hidden proportion, when it has been disturbed by the disease. In the state of good health is the very nature that restores or, if you will, is itself the right proportion. The concept so important to 'blend', actually means a kind of balance of body forces, closely connected with that of proportion and symmetry. The nature of work in the sense of a sensible norm. Comment on Real: These concepts of 'proportion', the 'symmetry', as well as those of 'more' and 'less', connecting closely with the concept of "measure", rather than "right size": this is the key concept of Platonic metaphysics, on which it depends to health. Health: "right fit", "harmony", "balance" The concept of health then, for Plato, it depends on the "right fit" or proportion of the parts of the whole organism of the human person, and this is the essential ontological character of reality same. The conclusion is that you can not treat the human body without addressing the totality of the body. But even you can heal the body, or a part thereof, without even cure his soul, his psyche, ie the totality of man. This is confirmed by the latest medical research, where it is increasingly clear that the explosion of a disease, be it organic or psychological, is always the culmination of a story with complex ramifications and not always easy to decipher, however, where it is clear that the ultimate roots of evil invariably belong to two orders that constitute us, the body and the spirit. There is always a connection between the two dimensions, even if the specific origin is in either dimension. In connection with the plan of life, the person's health is therefore to be considered in a dynamic way, as tension to establish a balance between the different dimensions that make up the human person, and in the multidimensional sense that concerns man in his unit and in 'articulation of its size. Health can still be understood and studied at different levels, from the physical and psychological, to the level of interaction between the body and the psyche, or a good balance between individual and community. It should however be understood in its entirety 
then targeted on the basis of the "meaning of life" and located a spirit level: human well-being depends essentially on living a meaningful existence. And 'therefore a dynamic-evolutionary condition and not a "state" fixed and stable, but a point of arrival, a route to go, a vocation to answer in dialogue with other experiences of life: joy, suffering, disease, successes and failures, disappointments and achievements. It meets the human subject in the first person, because it is not a condition that just "happens" to the man, an event which should only take note, but it involves a definite stance on the part of man. Also in this case the man is a "you decide", that decides about himself, the manner in which it now intends to handle this situation. And 'note the definition of WHO's health since 1948 as a "state of complete physical, mental and social." Therefore understand properly the condition of man, means inscribe in their personal "biography", ie taking it in his conscience, make it the object of decisions integrated into a framework of values within which be implementing their own existence. Summarizing, I would say that the state of man's integral well-being can be understood in various ways, depending on the level of integration of man's essential dimensions: a) at a first level, which depends on the good functioning of the organism. We are in the order of the plant or animal life; this first conception of health is dependent on the condition of well-being of the human person, solely or mainly on the person's well-being. To which the man gets sick when there is a dysfunction in his psychophysical organism. In this case, health is the recovery of the lost wealth, and if it is obtained, it is considered life existentially over, meaningless.(20)

b) At the second level, health is seen in the order of interaction between body size and mental and moral dimension of man, as well as the good relationship between the individual and the community. The spa at this level is primarily a condition of equilibrium: within the subject in the first case; Good personal relationships in the second. If that balance is missing, here is the "disease" and "ill-being"; the state of health is in restoring the right proportion.

c) The third level of the concept of health, refers to the "meaning of life", and is located in the order of the spirit: human well-being now depends on living a meaningful existence. As there are many examples of men and women who have given meaning to their lives while living it in situations of poverty, or suffering, of illness or misfortune! Experience shows, then, that the same condition of illness or suffering of another, does not necessarily exclude the meaning that life continues to have. The subject experiences this inner balance, this paradoxical correspondence between the condition of poverty or pain, and their own life project. Sometimes it even get the impression that the same pain, misfortune, illness or other, play a positive role in conferring an important meaning to life. Not the evil in itself is capable of so much, but rather it is the attitude with which the person lives that experience to confer this sense. It seems therefore that even a disease, or another experience pain and sorrow, can play a sort of "task" or function in a life "significant." In a personalistic conception of health, it is clear that the three levels that I mentioned, are designed in mutual reciprocity: what happens at one level, is reflected in the other, as there is a deep connection between biopsychic size, socio-environmental and ethical -spiritual. The person "healthy", then, is first of all he / she who lives in a harmonious and balanced manner the relationship between these different dimensions of health, in an order that tends to the affirmation of a meaningful existence. And 'therefore also capable of integrating the inherently limited character of man, and does not allow you to isolate health since suffering ... A healthy man should also be able to face suffering, he is called to live it .. . you can not detach the subjective experience of a person from the values with which that person faces life. there can be a positive experience if you can not make sense of suffering, to the limit and death. $(21,22)$

\section{EXISTENTIAL ANALYSIS OF THE DISEASE STATE}

To the extent that is emerging this conception of good or bad health condition, it understands the need for medicine, having to move from one approach to the person primarily of sick character "natural" and "objectivist", an attitude that embraces "subjectivity" of the patient, her past psychological, social and spiritual. At this stage of our reflection, it is essential that the health care professional is aware of what happens in the sick person. The human sciences and philosophy, especially that attentive to 'Humanum', applied to the world of health, they offer a very thoughtful and provocative description of the existential condition in which people suffering from a serious medical condition. E 'was above all the existential analysis of this situation to describe acutely real and what is happening in the inner space of the person seriously ill. I present concisely the results. In this case, the existential analysis is to describe "how the man in suffering." We must begin by recalling the human figure in his opening to life. Now the man emerges into existence, by asking questions; He is a seeker of meaning. Kant summed up that incessant ask three key questions: What can I know? What should I do? What can I hope? These questions arise on the spur of the desire for life, then he asks to be made true in a specific project. This is then implemented through a network of relationships that the subject establishes with others, with things and with the environment and with himself. Whether it is of a believer, it is also crucial the type of relationship that he lives with God. If we take into account cross this attitude with which the human person is placed in life, you realize what is happening in his inner space when surprise and overrun with a serious illness. That desire for life and the existence of the project are now being questioned, if not crushed. The new condition of life is first lived as a negation of the vital dynamism. Change the attitude towards existence under the pressure of a life form that is especially expressed as a breakdown in communication with the reality of existence. We can clarify this statement by resorting to studies on the disturbance produced by the "disease state". (23)Reflexive analysis the disease is as "a concrete form of existence, not reducible to pure organic accidental." From the point of view of phenomenology, disease status is expressed as pain and weakness. For the sufferer becomes essential anxiety of what will come next. On a purely psychological level, there is a narrowing of his world, a self-centered attitude of tyranny and addiction at the same time. At a deeper level, in the interior and existential space, you can be glimpsed:

a) The occurrence of a subjective unit break, a fracture between "body" and "cogito". The body degrades in "object representation", is unrelated to the subject of acquiring a condition of otherness and strangeness: psychosomatic states, 
such as fatigue, fever, pain, showed a rupture personnel unit, an inner disharmony; b) Towards others and things, the sufferer experiences a crisis of communication and interpersonal relationships. The disease fact compels the sufferer to attention almost exclusively to itself, which in itself implies the darkening of the consciousness of others. The universe shrinks in your room. It has a strong awareness of the dependence on the 'other self, which is the loss of autonomy;

c) the power of attorney disease a strong experience of limits: it is known that this experience arises fundamentally from the inadequacy of the ego with itself, there is therefore innate and always accompanies our consciousness. But there is a pathological condition in a specific manner, concrete and immediate experience of the radical fragility of one's being. And 'experience of limits of life, in its duration and in its quality. For this reason the idea of death is always present, albeit in different forms and at different levels of consciousness, in every type of disease;

d) you can then derive a feeling of dereliction especially if the evil is getting worse and branching, or you see a way out. And 'the feel abandoned, "thrown away" from life, as a last and summary accordingly. Have various moods that lead: the anxiety of the post, the sense of boredom and frustration, existential emptiness, the feeling of inconsistency of all, fear, boredom, sadness. It 's all a path that leads to the annihilation of personality. It 'a state of anxiety that threatens to invade the entire inner space of the person. If there is a sense in this situation, it is easy to fall into obscuration, in rebellion or despair and see the disease in view of the totality of the person. Now more and more and the empirical sciences, and humanities and philosophy, they inform us that this patient's state of existence is not a "neutral" condition in respect of organic disease. If health and disease, as I quickly called, must be read and interpreted in the light of the complex and articulated unity of the human person, it is clear that both the diagnosis and treatment should take into account the totality of the subject, the diversity and complementarity of size compose it. You can not, in other words, treating the biological dimension, regardless of "taking care" of the entirety of the person, because "sick" is not so much a "part" of the person, but is the subject that is such. It must therefore implement a shift "from the illness the sick person". In medicine so-called "natural" there is a darkening of subjectivity, which is put in brackets. The new approach that is being born, or which in many ways is re-emerging, asks to introduce the subject in the same biology; short calls attention to what is specifically "human" in sickness and in care. Healing in fact, in this perspective, it is no longer seen as mere reintegration into previous state, but as an existence regain by the patient. By itself the cure always involves a novelty in the patient compared to the previous condition; It includes an increase in the consciousness, of a change in lifestyle, a different understanding of self and others. This type of healing, can not exist without the active participation of the patient: the subject - that is, the sick - is the fundamental unifying moment between the different dimensions: biological, psychological, relational, which then converge on the personal biography of the subject itself. But it is the subject itself which can hinder this dynamism, because they generally prefer to delegate to others "specialists" in the industry, responsible for managing the process of the disease and therapy. The greatest obstacle to the integration of the illness or healing process in the biography of the subject, to say the scholars of the phenomenon, is in not wanting to see the truth in other aspects of our spiritual life. And this concerns both the patient and the physician. Bioethics wants to help deal with this task, in the belief that you can not have a proper orientation toward life, understood in all its forms, even those tiring and painful, if not through the assumption of responsibility in the management of existence $(24,25)$. In the case of disease-healing, liability case concerns both the health professional that the patient, to be exercised in a different way by each other, but always in mutual complementarity. Mostly we have the tendency to oppose the two attitudes that they face to the disease: understanding and delete. We just play the first function of the second. And if it happens, it remains in the disease with all the risks that I reported above. As should learn to integrate those two attitudes, identifying the position that healing is still in the very first attitude: in fact understand the meaning of the symptom, in itself it brings in a certain sense to integrate it, to add that in a broader context of meaning of life. And yet it is clear that the doctor is asked to deal with a specific dimension of the human subject, ie organic aspect. Yet, from the perspective of "cure and care" he will constantly present the entirety of the sick person, including attention to the proper subjective dimension of the patient. $(26,27)$

\section{WHAT IS "RATIONAL" FOR THE WORLD OF HEALTH?}

Compared to the promising development of neuroscience, and attention to the marvelous progress of modern medicine, however, it remains perplexed by the emergence in recent years, within the cultivators of the same medical sciences, of a strong trend that refers only the technical-scientific rationality for understanding the reality of life and of human life itself. Recent acquisitions extraordinary understanding of the human brain, are considered by many scholars to such a value to consider them the "turning point" more radical than any change that so far human history has known. And yet, from these acquisitions they originate questionable claims of some scholars of this trend. They believe that only this kind of rationality is capable of understanding the reality of human life, and therefore it can only tell us what human life in its origin, in its development and in its decline; also they claim that only this science can and must address the problems of bioethics and humanization, or there is more to expect reliable answers from philosophy, ethics, religion or human and theological sciences; and it is just this kind of science that can give sensible answers to the questions of "who" or "what" is the man, when and why it actually becomes "human beings" and when and why you fell from this condition. The reason that justifies these statements are essentially the epistemological status of the techno-scientific rationality: this deals with the given immediate and immediately perceptible, empirically verifiable, while the other rationality remain ambitious and smoky in their results, always postponing to an indefinite "beyond" achieving the goal of happiness.(28.29) For this, they conclude, the techno-scientific rationality is the only proper use of human reason. And this is where the error: reduce the way of seeing and understanding the human life to what happens in it only biologically, neglecting what is the 
proprium humanum, that man as such. The medicine in the time of modernity If we wanted to trace the origins of this thought, we should take care of two problems: one concerns the history of thought in the West, the other that of knowledge, scientific and philosophical. In fact, we should revisit the eighteenth-century Enlightenment, and some of his deviance in modern and contemporary. These seem to have originated the claims of some researchers, for which reason it is conceived only in the version empirical-positivistic. But we should also analyze the cognitive dynamics of the human person according to what they tell us the sciences, natural and human perception. We should understand what requirements or "prejudices" that allow people to know and to progress in his cognitive capacity. Would emerge as the "mental patterns of perception" that if on the one hand enable man to know and to evolve his mind, on the other hand can also block this dynamism, leaving him "fixed" to previous thought patterns or mental patterns reductive. I do not think that this is the moment to go into these issues. Here it presses rather occur in practice these claims of that kind of rationality applied to health care world. For if now all of Western medicine is committed to recovering his ability to understand the patient's person in the multiplicity of its dimensions for a proper diagnosis and appropriate therapy, doubts inevitably arise in relation to such claims and pretensions(30.31)

\section{REFERENCES}

[1] Cfr. E.D.Pellegrino, D.C.Thomasma, For the Patient's Good. The Restoration of Beneficence in Health Care, Oxford University Press, New York 1988. Il modello della beneficence in trust: alla fiducia nella persona del medico deve corrispondere la disposizione di quest'ultimo ad agire per il bene del paziente. L'obiettivo comune per il medico ed il paziente è agire nel migliore interesse l'uno per l'altro.

[2] Ci testimonia ciò il Papiro di Ebers (1500 a.c.), forse il primo libro di medicina, così afferma J. Starobinski, Storia della Medicina, trad.it., Mursia, Milano 1954.

[3] Non ci soffermeremo in questa sede sul rapporto tra la medicina e le altre religioni. Ci pare però opportuno segnalare una pubblicazione sulle tradizioni ebraiche, cattoliche, protestanti, ortodosse, islamiche, induiste e buddiste: AA.VV., Salute malattia e morte nelle grandi religioni, a cura di A. Pangrazzi, Torino 2002

[4] F.D.Tosto, Ultimi o primi? Infirmi e disabili nella storia sociale e letteraria del Cristianesimo, Editrice Istina, Siracusa 2012.

[5] Su questi concetti si veda A. Pazzini, Medici in cammino, Hoepli, Milano 1942; J. Jouanna, Ippocrate, trad. it., SEI, Torino 1994; G. Mottura, Il Giuramento di Ippocrate. I doveri del medico nella storia, Editori Riuniti, Roma 1986

[6] M.Balint, Medico,paziente e malattia, Feltrinelli, Milano 1990.

[7] U.Veronesi, Pasteur. Dalla nascita della Medicina moderna alla lotta contro il cancro. La biblioteca della Repubblica, Roma 2012.

[8] Cfr. E. Shorter, La tormentata storia del rapporto medico-paziente, Feltrinelli, Milano 1986

[9] G. Bert, Per un miglior rapporto tra medico e malato: un traguardo possibile. Rec. Progr. Med.2006; 97: 548-555

[10] T.Gordon, Insegnanti efficaci, Giunti Lisciani, Firenze, 1991.

[11] S.Brehm, Psychological reactance, Academic Press, London 1981.

[12] E.Shorter, La tormentata storia del rapporto medico-paziente, cit.

[13] Vedi British Journal of General Practice: 54:922-7, 2008.

[14] Origene, Adnotationes in librum III Regum (PG 17,53-56) citato e tradotto da U. Mattioli, Assistenza e cura dei malati nell'antichità cristiana, in AA. VV. Cultura e promozione umana, Convegno internazionale di studi Oasi di Troina (EN), Troina 1998.

[15] S. Boezio, Contra Eutichen et Nestorium, c. 4. Per Boezio sono persone tutti gli esseri umani, anche quelli che a causa di un grave handicap mentale non indicano operazioni della ragione.

[16] Cfr. P. Singer, Etica pratica, Liguori, Napoli 1989. In questo caso nella vita vegetativa persistente cessa la vita personale e rimane la vita biologica, che da sola non può dare ad un essere il connotato di persona. Nel malato terminale o nello stato vegetativo c'è la vita biologica ma è cessata la vita biografica. Il corpo è vivo ma la persona non lo è più. Tali esseri vivi soltanto in senso fisico, senza nessuna prospettiva di riacquistare la coscienza, non hanno nessun connotato di persone. Seguendo i presupposti singeriani, il cerchio dell'etica non soltanto lascia fuori gli esseri umani incapaci di soffrire, ma anche tutti quelli che non sono solo in grado di soffrire. Ciò giustifica la soppressione di tutti quegli esseri umani la cui vita sarebbe così penosa da non essere degna di essere vissuta.

[17] Cfr. G.Castelli, Ritorno da Benj Suef, Editrice Istina, Siracusa 2015.

[18] Gaudium et Spes, 12.

[19] F.D'Agostino, Parole di Bioetica, Giappichelli, Torino 2003.

[20] H.G.Gadamer, Dove si nasconde la salute, tr. it., Raffaello Cortina Editore, Milano 1993,107.

[21] Si osserva infatti che "sia nella sua forma romanica che in quelle germaniche e slave (rom.: salus, salute, salut; got.: hails, paleoslava: celu), il termine denota radici indogermaniche che stanno a significare 'essere-integro'.

[22] Per la cultura occidentale ritengo di notevole interesse, per il tema che ci occupa, un recente saggio di Giovanni Reale: Corpo, anima e salute. Il concetto di uomo da Omero a Platone, Raffaello Cortina Editore, Milano 1999. Vi viene recuperato il senso dell'integrità della persona umana. Propriamente, lo stato di salute è inteso come "giusta misura", equilibrio, armonia e integralità della persona. In un confronto serrato con i testi di Platone, l'Autore dimostra come il grande filosofo greco, partendo dal concetto di salute che gli forniva la medicina del tempo, l'ha poi ampliato e fondato sui principi della sua filosofia, pervenendo ai fondamenti metafisici dell'essere. Il fulcro attorno al quale ruota il concetto di salute, è visto nella "misura e proporzione conveniente"

[23] W.Jaeger, Paideia. La formazione dell'uomo greco, tr. it., Bompiani, Milano 2003.

[24] Cfr. G. Reale, Corpo anima e salute, cit.

[25] Una buona interpretazione in tal senso è offerta da V. Frankl, Logoterapia e analisi esistenziale, Morcelliana, Brescia, 1974.

[26] G.Cinà, E.Locci, C.Rocchetta, L.Sandrin, Dizionario Teologico di Teologia Pastorale Sanitaria, Ed.Camilliane, Torino 1997, 1081-1082; si veda anche: A.N.Terrin, L'impotenza di fronte alla sofferenza e l'emergere del concetto salute-salvezza, in: Credere oggi 1 (2005), 25-27. V.Frankl, Alla ricerca di un significato della vita, Mursia, Milano 19932; Id., In principio era il senso. Dalla psicoanalisi alla logoterapia, Queriniana, Brescia 1995

[27] Vedi M.Merleau Ponty, Il primato della percezione, Medusa, Milano 2004.

[28] Oggi, nello spostamento delle "cure a domicilio" del paziente dimesso dal centro sanitario, è più facile verificare l'inizio di questo "passaggio" si veda in S.Spinsanti, Curare e prendersi cura, Ed. CIDAS, Roma 1998, 113-124. Ovviamente, la "riduzione" della razionalità entro l'ambito tecno scientista, non riguarda solo le scienze mediche: oltre ai due discorsi di Benedetto XVI, si può vedere anche: I.Sanna, L'antropologia cristiana tra modernità e postmodernità, Queriniana, Brescia 2004; L.Casula e G.Ancona, L'identità e i suoi luoghi. L'esperienza cristiana nel farsi dell'umano, Edizioni Glossa, Milano 2008.

[29] Ibidem

[30] Vedi S.Rachamandran, Che cosa sappiamo della mente, Mondadori, Milano 2004; M.S.Gazzaniga, La mente etica, Codice edizioni., Torino 2006.

[31] Allport G.W., Psicologia della personalità, PAS-Verlag, Zurigo 1973, pp.220-234; L.M.Rulla, Antropologia della vocazione cristiana, Piemme, Casale Monferrato 1985, pp.89-143. 165-199. La vita dalle fondamenta: "perché, e perché proprio ora, e perché a me? Ha ancora un senso la vita? Valeva la pena di nascere se poi bisognava arrivare a questo?...Alla fine, insomma, chi sono io?" 